Department of Morphology (Prof. K. Kurosumi), Institute of Endocrinology, Gunma University and First Deptartment of Surgery (Prof. K. IsHiHARA), Gunma University

School of Medicine, Maebashi, Japan

\title{
Experimental Morphological Studies on the Parafollicular Cells of the Rat Thyroid Gland, with Special Reference to the Source of Thyrocalcitonin*
}

\author{
Tatsuji Matsuzawa （松沢達治）
}

Received August 17, 1966

The term "parafollicular cell" was named by NoNIDEZ (1932) for a special cell type different from the ordinary follicular cells in the dog thyroid gland. The parafollicular cells occur along the basal surface of the follicular epithelium in most mammalian thyroids, and never face the colloid-containing follicular lumen. Morphological studies have been carried out by many investigators, but the functional significance of this cell has not been clearly interpreted. On the other hand, a serum-calcium lowering factor which was found by CoPP et al. (1962) and was recently confirmed to be contained in the thyroid gland by HIRSCH et al. (1963). This new thyroid hormone is called calcitonin (COPP et al. 1962) or thyrocalcitonin (HIRSCH et al. 1963). On the basis of the data concerning enzymatic activities as demonstrated by histochemical examinations, FOSTER et al. (1964) suggested that the thyrocalcitonin might be secreted from the so-called mitochondrion-rich cells of the thyroid. But the identification of these cells with the parafollicular cells could not be established. In order to elucidate a possible relationship between the parafollicular cell and the hormone concerning the calcium metabolism, light and electron microscopic examinations were performed on the thyroid glands of normal and calcium-injected rats. The thyroids of hypophysectomized rats were also observed for the clarification of the hormonal dependency of the parafollicular cells.

\section{Materials and Methods}

Adult rats of Wistar strain were used as experimental animals. Prior to each experiment, all animals were fed with a standard compressed diet (Oriental Co., Tokyo) and kept at a room temperature of $20--25^{\circ} \mathrm{C}$ for $2-3$ weeks.

1. Physiological examination

As a preliminary experiment, the influence of intravenous injection of calcium solution on the serum calcium level was observed. Forty female rats weighing $140-200 \mathrm{~g}$ were used. Ten rats out of the forty were reserved as a control without the following treatment. $1.0 \mathrm{ml}$ of calcium chloride solution, containing $10 \mathrm{mg}$ of calcium ion per ml was injected $1.0 \mathrm{ml}$ per $\mathrm{kg}$ of body weight into the femoral vein of each experimental animal under a slight anesthesia with ether. The blood of each animal was collected on decapitation at 5, 15, 30 minutes and $1,2,3,4,5,6$, and 7 hours after calcium injection. The serum was separated immediately. The measurement of total calcium level and of the protein content in the serum was carried out by means of a flame-spectrophotometer and a protein refractometer respectively.

\footnotetext{
* This paper is dedicated to the memory of the late Prof. Masaji SEKI,
} 


\section{Preparation of mor phological sxeimens}

For electron microscopy, six male rats weighing $140-200 \mathrm{~g}$ were used in the first series of experiments. Two of them were employed as a control and four rats were injected intravenously with $1.0 \mathrm{ml}$ of the calcium solution per $\mathrm{kg}$ of body weight by the same method as in the preliminary experiment mentioned above. They were sacrificed 2 and 4 hours after calcium injection, and their thyroid glands were romoved. One lobe of each thyroid gland was immediately fixed with osmic acid solution buffered at $\mathrm{pH} 7.4$ and made isotonic as introduced by CAULFIELD (1957) for 90 minutes, while the other lobe of each thyroid was fixed with $6 \%$ glutaraldehyde buffered with cacodylate- $\mathrm{HCl}$ at $\mathrm{pH} 7.4$ for 90 minutes and then postfixed with Caulfield's osmic acid fixative for the same period.

In the second series of experiments, ten male rats weighing $140-200 \mathrm{~g}$ each were hypophysectomized by the transauditory method of KoyAmA (1962) and were sacrificed at 3, 5, 7, and 10 days after the oparation. One lobe of each thyroid gland was fixed with the Caulfield's fixative and the other lobe of the same gland glutaraldehyde followed by the Caul. field's fixative.

In order to remove contaminated formic acid, commercial glutaraldehyde solution indicating $\mathrm{pH} 2.4$ was passed through a columm of anion exchange resin (Dowex-1), and the stock solution of glutaraldehyde showing $\mathrm{pH} 6.8$ was obtained.

The specimen either fixed with osmic acid or glutaraldehyde followed by osmic acid were dehydrated with a series of ethanol of ascending concentrations and were embedded in Epon 812 by the method of LuFT (1961). They were sectioned with a Porter-Blum ultramicrotome and were doubly stained with a saturated aqueous solution of uranyl acetate and lead hydroxide after MiLlonig (1961). An HS-7 electron microscope equipped with a modified electric source with high voltage stabilizer by feed-back mechanism, a double condenser system and a stigmator. Electron micrographs were taken under either 50 or $75 \mathrm{kV}$ of accelerating potential at 5,000-10,000 times electronic magnification, and thereafter enlarged photographically as desired.

For light microscopy, the thyroid glands of normal male rats which were fixed with $6 \%$ glutaraldehyde solution buffered at $\mathrm{pH} 7.4$ were embedded in paraffin and sectioned $4 \mu$ thick. Such specimens were stained with the periodic acid-Schiff method, azan or hematoxylin-eosin, and compared with those fixed with Zenker or Ciaccio fixative.

\section{Measurement of population density of secretory granules}

Fifty electron micrographs containing parafollicular cells which were taken from the specimens fixed with glutaraldehyde followed by osmic acid were taken at random for measurement from each of the four experimental groups, i. e., the control, 2 and 4 hours after calcium injection and 7 days after hypophysectomy. The cytoplasmic area of each cell was measured with a planimeter, and the total number of secretory granules contained in the same cell was counted. The population density of secretory granules in a given cell in each experimental group was indicated by the number of granules in a square micron of the cytoplasmic area.

\section{Results}

\section{Changes in total serum calcium content after calcium injection}

The control level of the total serum calcium was determined in ten normal animals. Each value was distributed from 5.68 to $5.96 \mathrm{mE} / 1$ and its mean value was $5.92 \mathrm{mE} / 1$. Immediately after a single injection of calcium chloride solution into the femoral vein, the total serum 
calcium increased suddenly and reached to the maximum $6.70 \mathrm{mE} / 1$ at 15 minutes after the injection, and from that time the serum calcium level decreased rapidly and almost sank to the control level at one hour after the injection. It is an interesting fact that the decrease of the total calcium content continues until four hours after the injection and the minimum value is far below the normal level, that is $5.03 \mathrm{mE} / 1$. Thereafter it in. creased gradually and recovered to $5.56 \mathrm{mE} / 1$ at seven hours after the injection. These results are shown in Fig. 1.

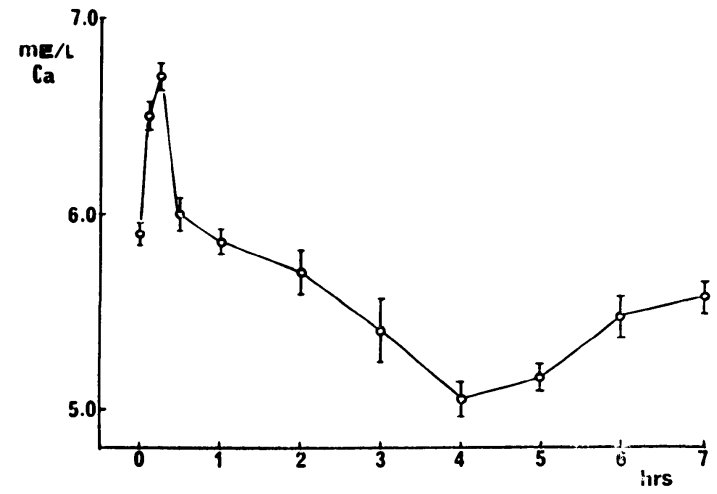

Fig. 1. Fluctuation of total serum calcium level after a single intravenous injection of calcium chloride solution. The indicated maximum value is $6.70 \mathrm{mE} / 1$ at $15 \mathrm{~min}$. af ter the injection, while the minimum is $5.03 \mathrm{mE} / 1$ at 4 hours after the injection, far below normal.

\section{General structure of the parafollicular cells.}

\section{Light microscopy}

Prior to the electron microscopic observations, thick sections obtained from the same specimens used for electron microscopy were stained with $1 \%$ toluidine blue solution and were observed under the ordinary light microscope. The parafollicular cells are seen somewhat larger than the follicular cells in size under normal conditions, and round or hemispherical in shape (Fig. 2). They occur singly or grouped and are in contact with the follicular epithelium. The nuclei are somewhat larger than those of the follicular cells. Their cytoplasm and nuclei are both weakly stained with toluidine blue as compared with those of the follicular cells. In hypophysectomized rats, the ordinary follicular cells underwent the atrophy and were flattened, especially remarkable for the nuclei, which were subject to pycnosis, while the parafollicular cells remained unchanged (Fig. 3). The parafollicular cells can be identified more easily and their localization was demonstrated more clearly in the thick sections of hypo. physectomized rats than in the specimes from the normal animals, when observed with the light microscope. The specimens obtained from the materials which were fixed with glutaraldehyde and were embedded in paraffin were also stained with the ordinary stain for light microscopy such as PAS-reaction, azan and hematoxylin-eosin, and compared with those fixed with Zenker or Ciaccio fixatives, but no marked difference could be found on the stainability of both the follicular and parafollicular cells.

\section{Electron microscopy}

The parafollicular cells occur among follicular epithelial cells and are covered with the common basement membrane and never face the follicular colloid. In hypophysectomized rats, a high degree of atrophy of the follicular epithelium is seen, but electron microscopic observations revealed that the parafollicular cell and the follicular colloid are still separated distinctly by a thin layer of the follicular cell. The parafollicular cells of ten bulge up towards the interstitial tissue. Sometimes a small round parafollicular cell looking like an islet can be observed within the follicular epithelium. The plasma membrane of the parafollicular cell is smooth, and no complicated foldings occur between the adjacent cells. The typical desmosomes are frequently seen between the parafollicular cells and the ordinary follicular cells as well as 

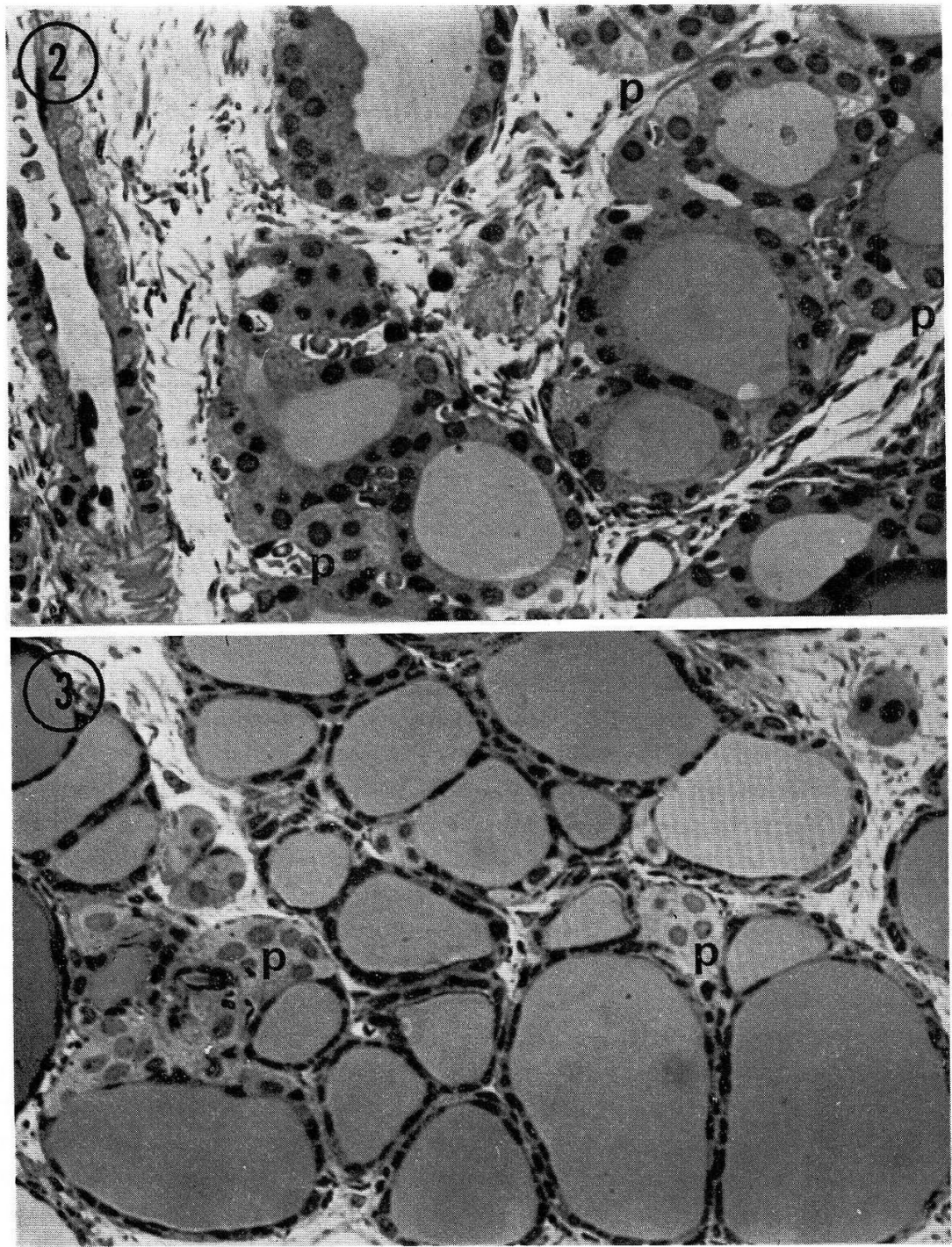

Fig, 2. A photmmicrograph of the normal thyroid gland. The parafollicular cells $(P)$ are distributed singly or in clusters. The nuclei of these cells are some shat larger than those of the follicular cells. Both the cytoplasm and nucleus of the parafollicular cell are weakly stained as compared with those of the follicular cells. Toluidine blue stained thick section of the $\mathrm{OsO}_{4}$-fixed, epon-embedded specimen. $\times 1,350$

Fig. 3. A photomicrograph of the thyroid gland 10 days after hypophysectomy. The follicular cells show the typical changes which follow hypophysectomy. They undergo atrophy and are extremely flattened. Flattened nuclei are subjected to pycnosis. The parafollicular cells $(P)$ remained unchanged in structure and seemingly a little greater in number than in the normal animal. The same technique in specimen preparation as in the above figure. $\times 1,350$

between the adjacent parafollicular cells themselves (Fig. 4). The desmosome-like structures, which are not typical, also occự bețween the parafollicular cells themselves, The nuclei are 


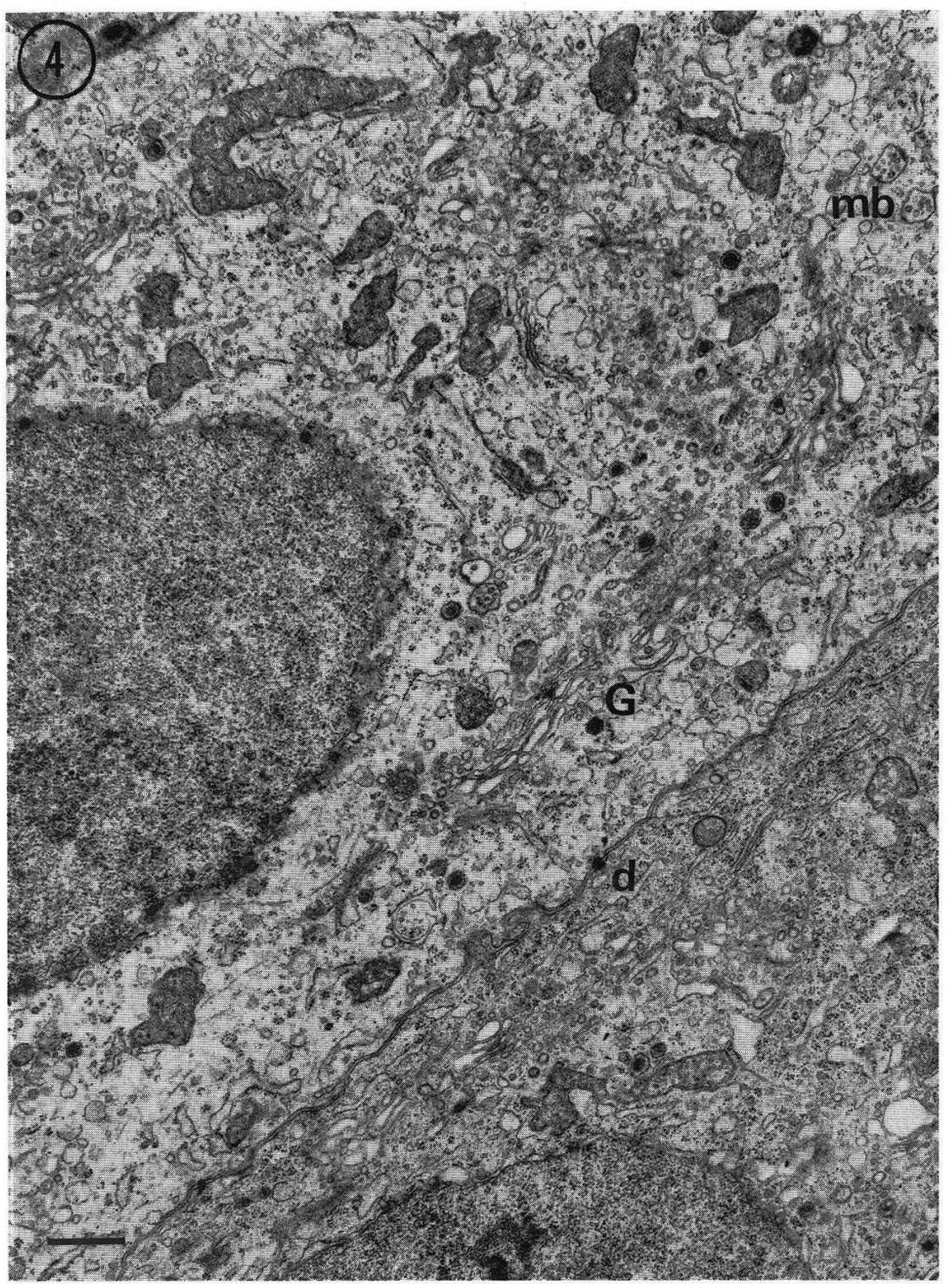

Fig. 4. Two adjacent parafollicular cells from the normal rat. The Golgi apparatus $(G)$ are well developed in the upper cell. Near the apparatus many small dense granules probably of the secretory nature can be observed. $d$ Desmosomes, $m b$ multivesicular body. $\mathrm{OsO}_{4}$ fixation. $\times 9,200$

round or oval and their surfaces are smooth in general and contain one or two nucleoli which are usually situated near the nuclear membrane. The mitochondria are round, oval or rod-shaped, though the last shape is most abundant, and they are scattered throughout the cytoplasm. Sometimes they showed a tendency to be clustered. Bundles of fine filaments may be observed in almost all of the parafollicular cells (Fig. 6, 7). The multivesicular bodies are 


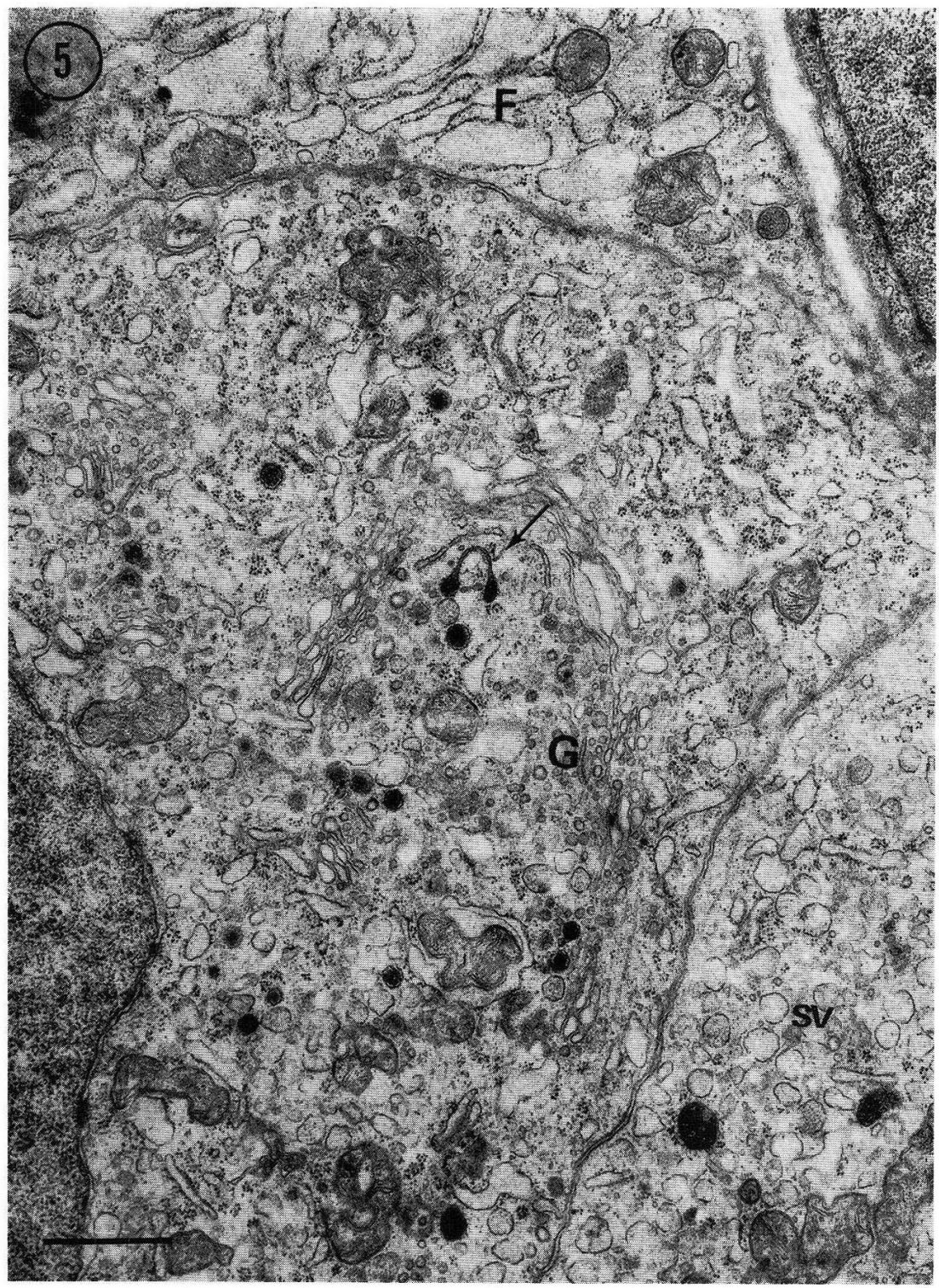

Fig. 5. A part of the thyroid of a normal rat. A small part of the eytoplasm shown at the top of the micrograph is of a follicular cell. The remainder consists of two parafollicular cells filled with many clear secretory vesicles $(s v)$. The Golgi apparatus $(G)$ is well developed and contains many dense immature secretory granules. A structure like a curved dumbbell (arrow) indicates the accumlation of secretory substance in a curved Golgi lamella with expanded ends. $\mathrm{OsO}_{4}$ fixation. $\times 15,000$

of ten found, but the centrioles and cilia are rarely observed (Fig. 6). The Golgi apparatus is well-developed and two or more clusters of the Golgi elements can usually be found in one cell (Fig. 4-6). Some vesicles or sacs of the Golgi apparatus may contain dense material, from which the secretory granules may be produced (Fig. 5, 7). The rough endoplasmic reti- 


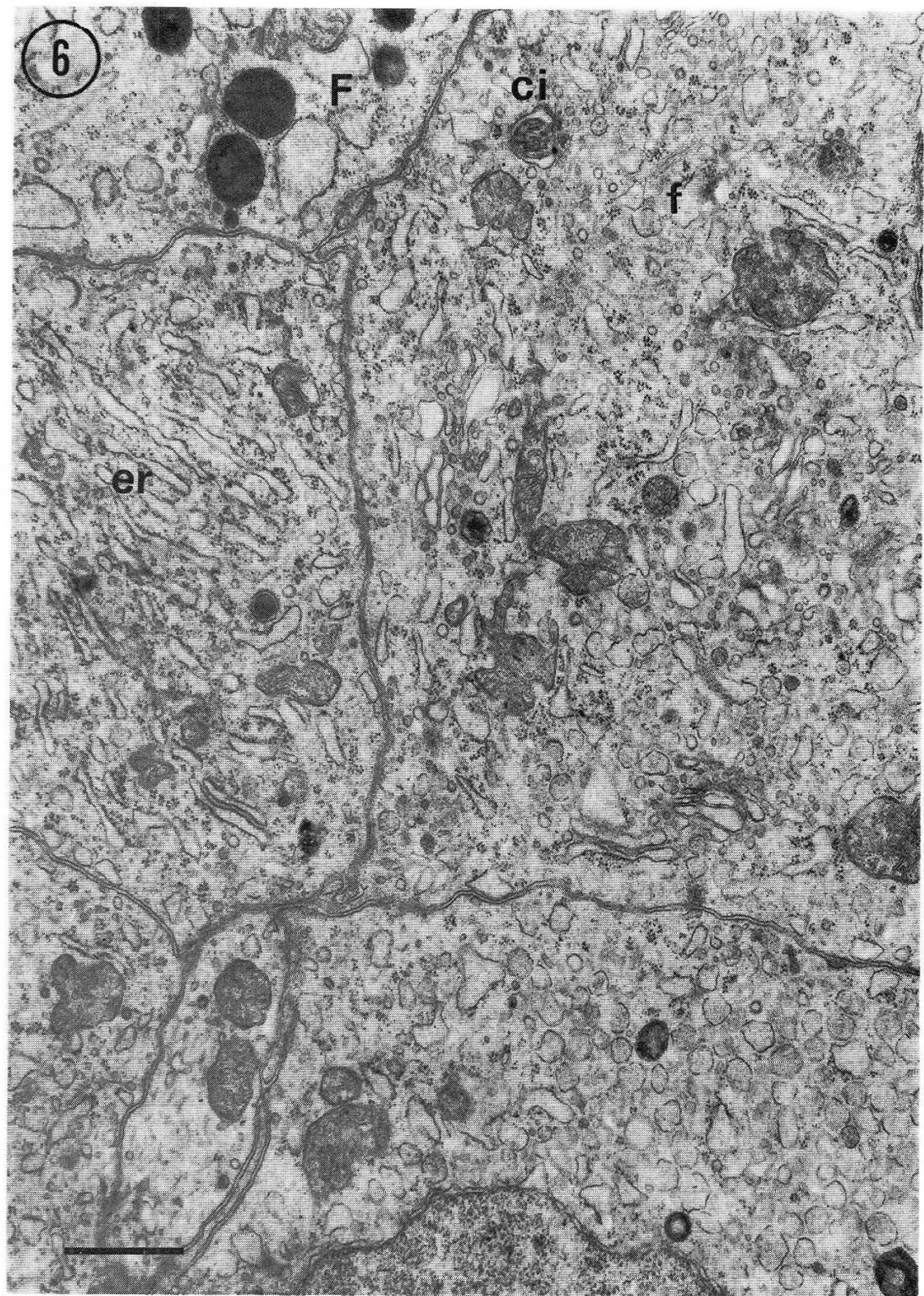

Fig. 6. A group of parafollicular cells of normal rat thyroid. A small cytoplas nic profile at the upper left corner is a follicular cell $(F)$. One of the parafollicular cells contains a cilium $(c i)$ and a bundle of fine filaments $(f)$ are seen in the upper part. The rough endoplasmic reticulum $(e r)$ is arranged in parallel lamellae in the left side of the micrograph. The cytoplasm of the lower cell is filled with abundant secretory vesicles. $\mathrm{OsO}_{4}$ fixation. $\times 15,000$

culum is moderately developed and usually arranged in the parallel lamellae (Fig. 6, 8). Free ribosomes, mainly grouped in rosettes, are abundantly scattered throughout the cytoplasm.

The most characteristic feature of the parafollicular cell is abundance of the secretory granules or vesicles. The secretory granules approximately $2000 \AA$ in diameter are generally 


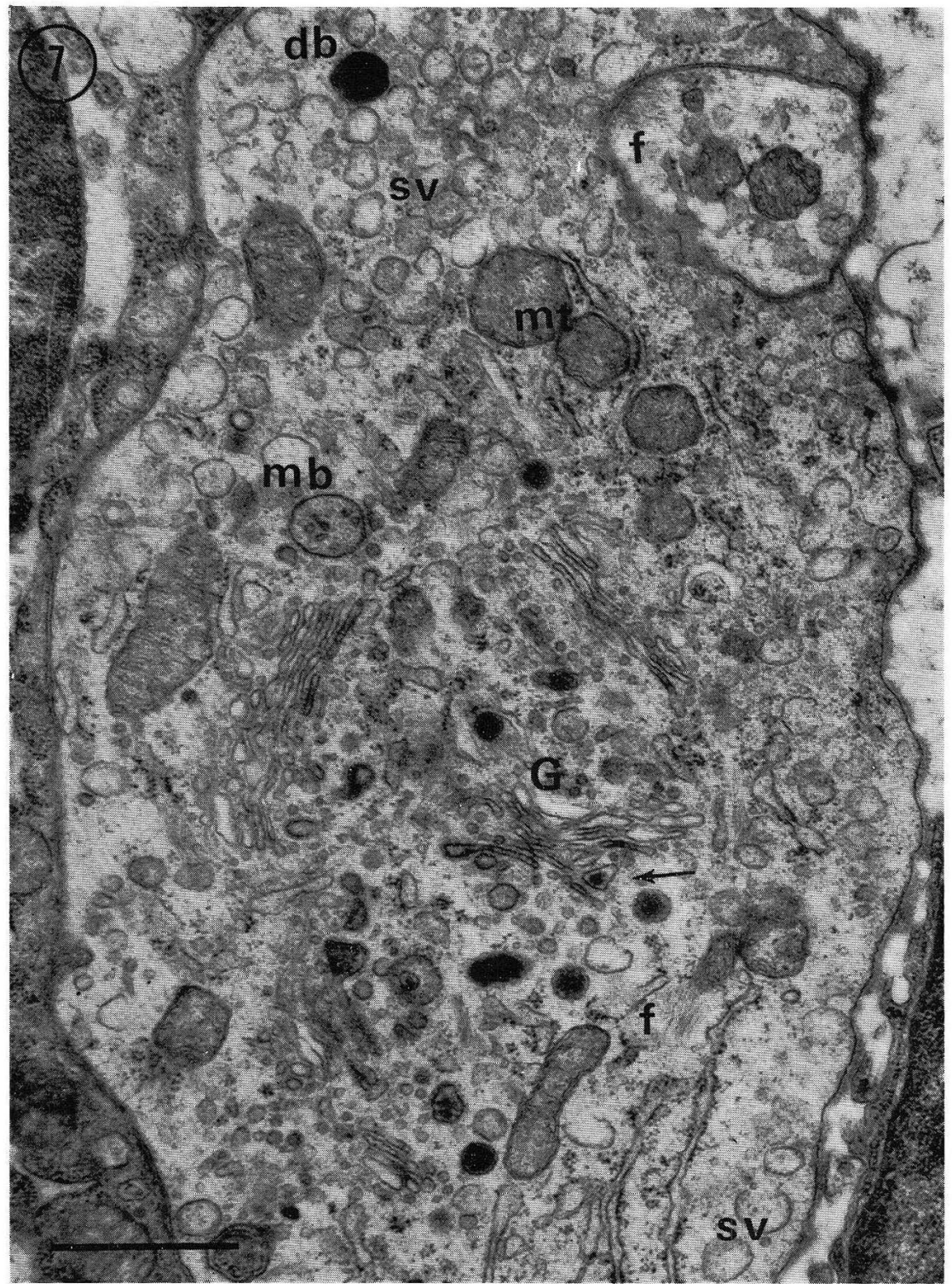

Fig. 7. A part of a parafollicular cell of the rat 5 days after hypophysectomy. Bundles of the fine filaments $(f)$ and clear secretory vesicles $(s v)$ are scattered through the peripheral cytoplasm. The Golgi apparatus $(G)$ is situated at about the center, in which small secretory granules are contained. An arrow shows the formation of secretory granules within the Golgi sac. Multivesicular bodies $(m b)$, mitochondria $(m t)$ and large homogeneous dense bodies $(d b)$ are situated around the Golgi apparatus. $\mathrm{OsO}_{4}$ fixation. $\times 22,500$

spherical and show a tendency to accumulate in the basal part of the cytoplasm adjacent to the basement membrane (Fig. 12, 13). After the single fixation with osmium tetroxide, only the secretory granules in the Golgi region appear as dense granules, but most of the granules 


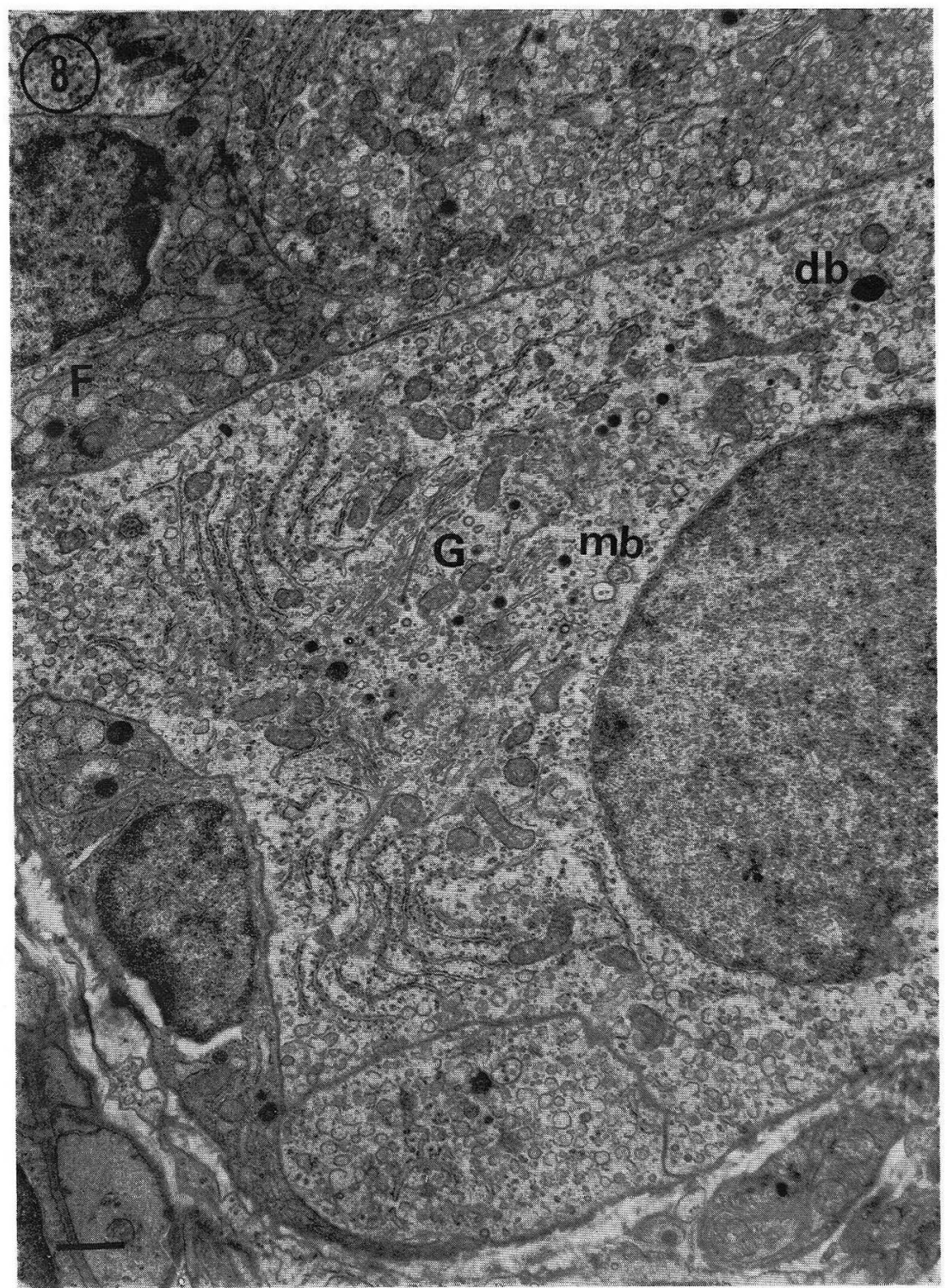

Fig. 8. parafollicular cells of the rat 10 days after hypophysectomy. Production of the seeratory granules is rather active in the Golgi apparatus $(G)$. Multivesicular bolies $(m)$ ) and large dense bodies $(d b)$ are contained. The left upper part is occupied by some follicular cells $(F) . \mathrm{OsO}_{4}$ fixation. $\times 7,700$

scattered in the general cytoplasm are seen as clear vesicles either containing less dense material or completely transparent in appearance (Fig. 5, 6). In the specimens fixed with glutaraldehyde followed by osmium tetroxide, the secretory granules are demonstrated as solid granules of high electron density (Fig. 12-20). However, the density of the granules varies considerably from granule to granule, also in the specimens made by the technique of this 

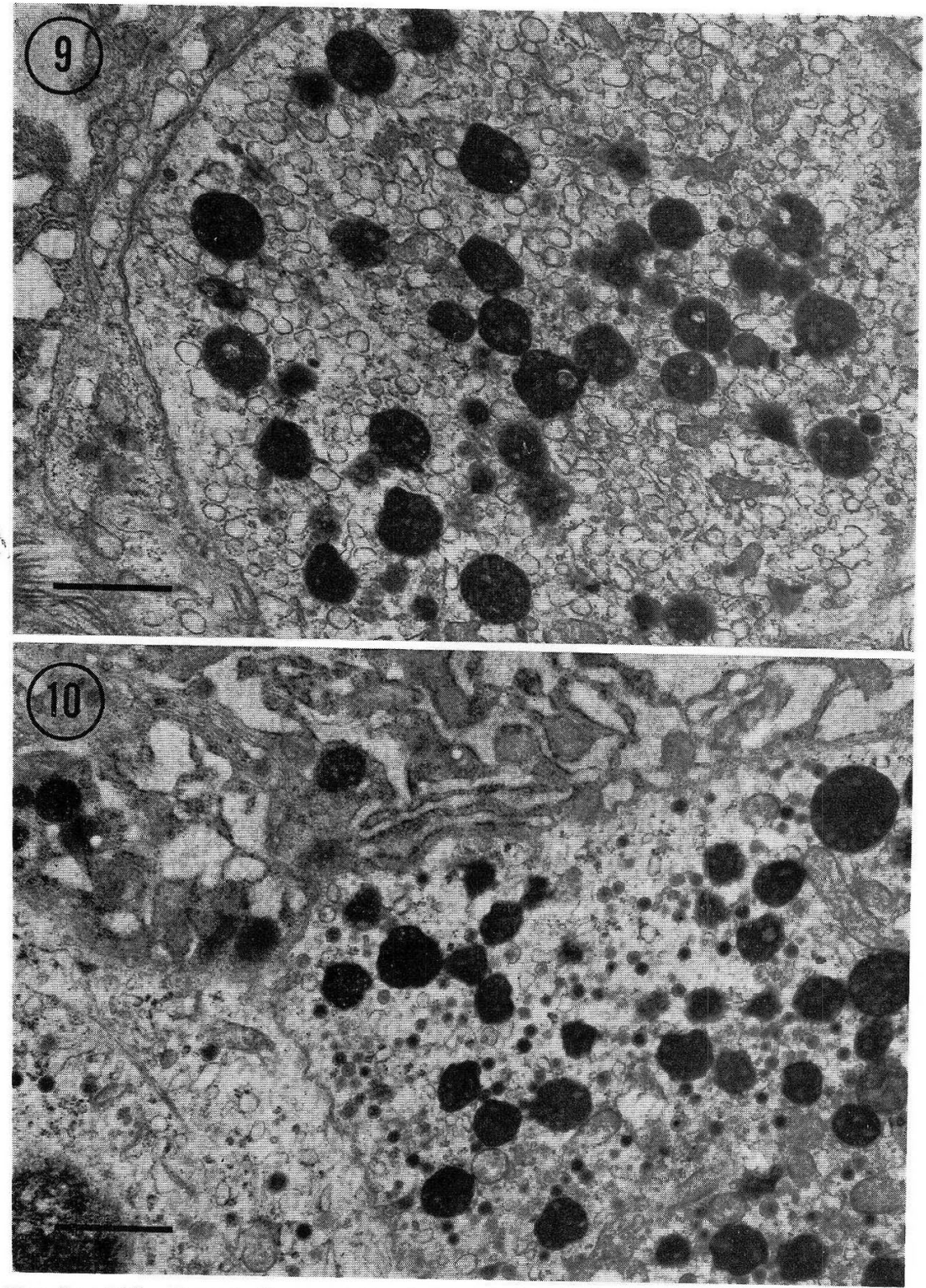

Figs. 9 and 10. Dense bodies occurring abundantly in the parafollicular cells. Some of the bodies contain clear vesicular spots. The parafollicular cell fixed with $\mathrm{OsO}_{4}$ alone (Fig. 9) contains clear secretory vesicles, while the cell after a double fixation with glutaraldehyde and $\mathrm{OsO}_{4}$ (Fig. 10) contains darkly stained secretory granules. $\times 14,000$

double fixation. It is observed clearly after glutaraldehyde-osmium fixation that the dense material contained in the secretory granules, which are situated along the basal plasma membrane, may be discharged through the small opening into the extracellular space facing the basement membrane (Fig. 18). This evidence clearly indicates the fact that the parafollicular 


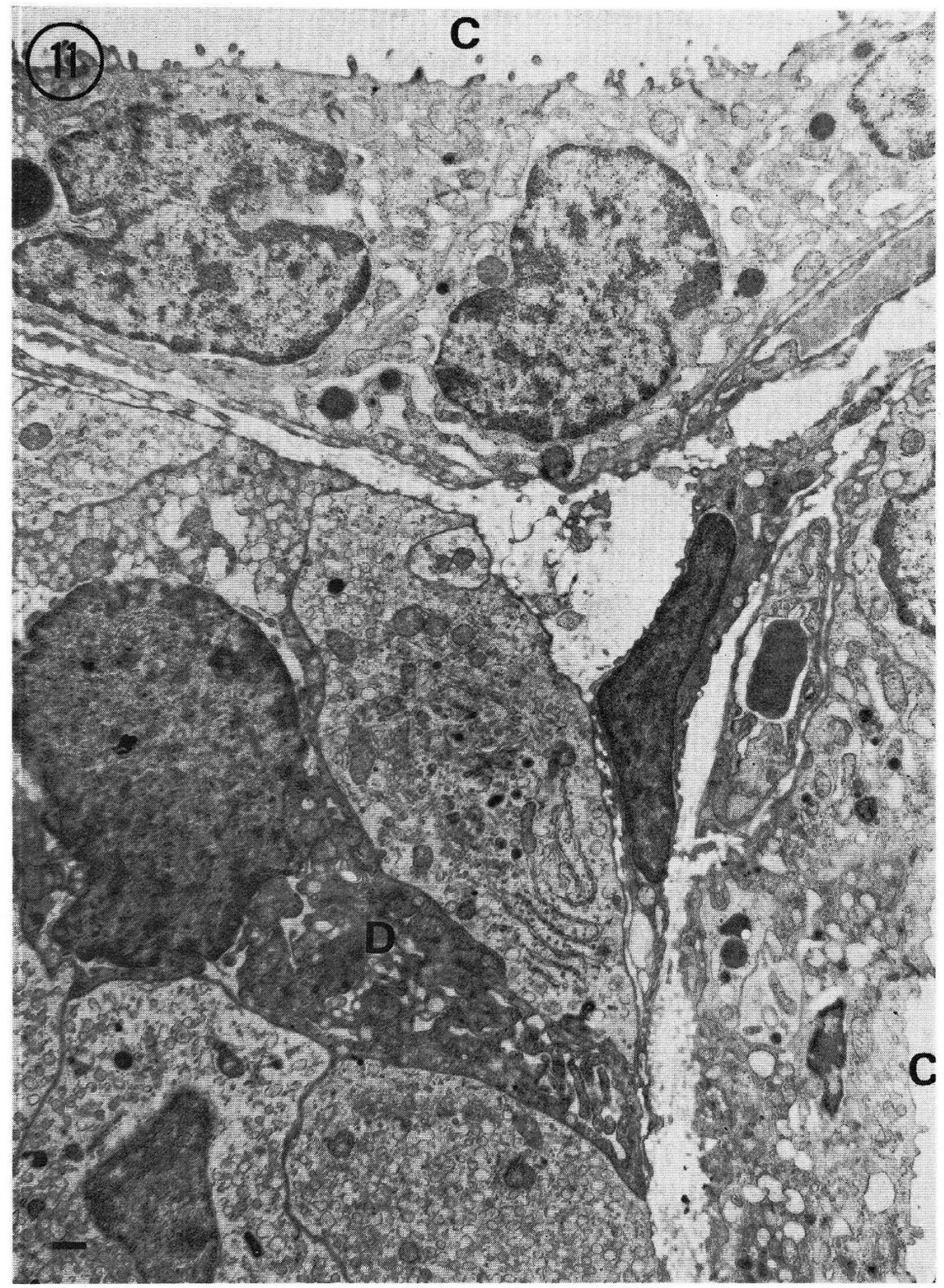

Fig. 11. A low power electron micrograph of the thyroid gland 5 days after hypophysectomy. The parafollicular cells appear in a group in the left lower corner. In the follicular epithelia, facing the luminal colloid $(C)$ are seen typical changes due to hypophysectomy. The rough endoplasmic reticulum of the dark cell $(D)$ is complicated in structure and is continuous to the perinuclear space. $\mathrm{OsO}_{4}$ fixation. $\times 4,000$

cell discharges their secretory substance by means of the mechanism of the so-called extrusion type IV (Kurosumi, 1961). 'The dense bodies may be found in the cytoplasm of the parafollicular cells of the normal and experimental rats. Two different morphological types are seen - the homogenous and vesicular types. The latter including vesicular substructures in the 
body is almost as large as the homogenous one, and sometimes tends to appear abundantly in one cell (Fig. 9, 10).

The dark parafollicular cells are occasionally found in each of the experimental groups (Fig. 11). They are variable in shape, but usually polygonal. The cytoplasm is dark and small in general, as it were compressed and condensed. The free ribosomes are relatively abundant. The rough endoplasmic reticulum is complicated in structure, and is continuous to the perinuclear space between the inner and outer nuclear membranes, the latter showing the irregular bulging. The Golgi apparatus of the dark cell is not so prominent, and the secretory granules are small in number.

\section{Changes in the parafollicular cells after calcium injection and hypophysectomy}

In order to clarify any change in the number of secretory granules in the parafollicular cells, the glutaraldehyde fixation followed by osmic acid is more useful than the single fixation with osmic acid, even though the latter is more effective in preserving the ultrastructure. After glutaraldehyde fixation some mitochondria tend to swell and the cristae are sometimes crushed. In spite of this failure to preserve the mitochondria satisfactorily, the secretory

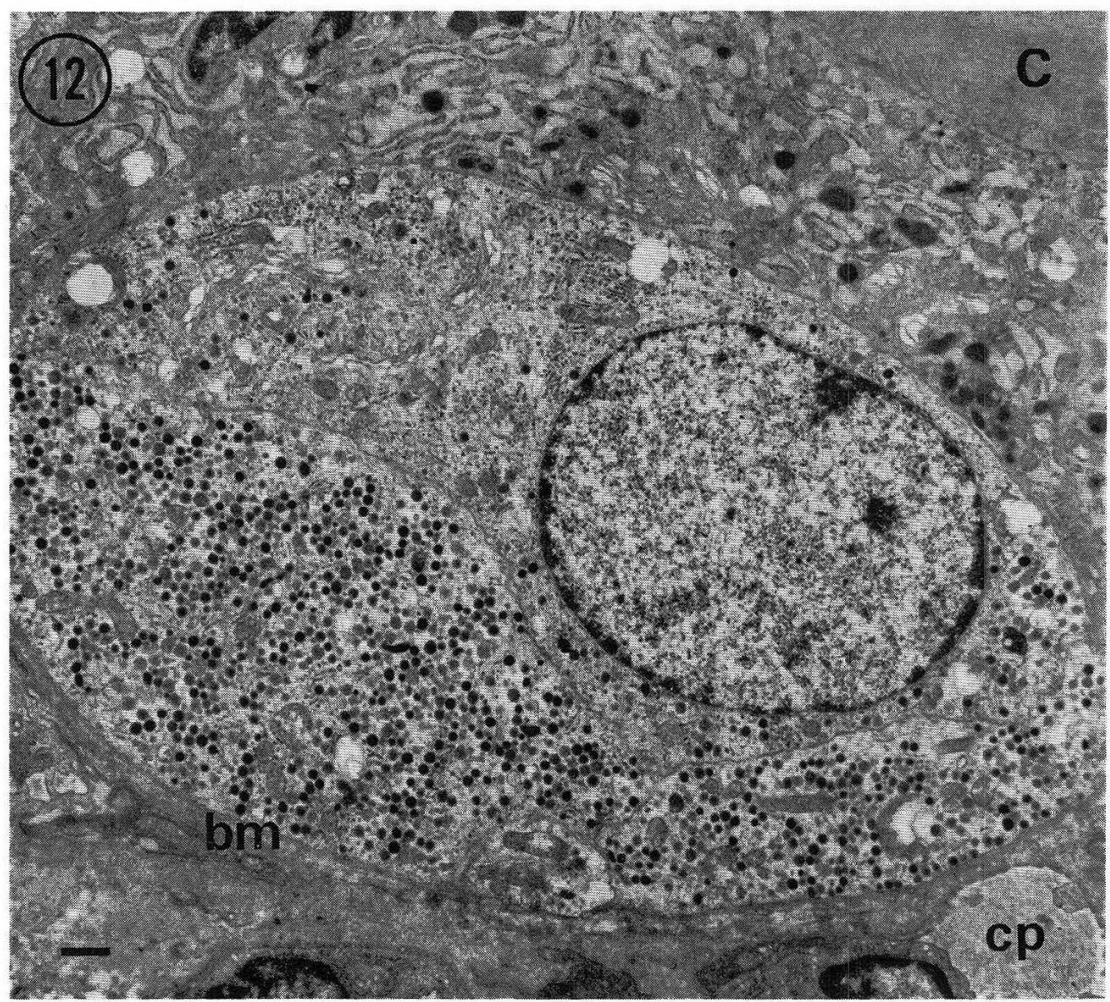

Fig. 12. The normal parafollicular cells fixed with glutaraldehyde followed by oxmic acid. The secretory granules tend to be accumulated in the basal part. The basement membrane $(\mathrm{bm})$ intervenes between the basal plasma membrane and the blood capillary $(c p)$ in the interstitial tissue. The colloid $(C)$ in the follicular lumen is seen in the upper right corner.

$$
\times 5,000
$$


granules are more or less dense after glutaraldehyde-osmium fixation, and there in no confusion of secretory granules, which appear as vesicles after simple osmium fixation, with vesicles of the other structural entities such as those of the endoplasmic reticulum or those formed by the pinocytosis.

In the normal control cells as shown in Figs. 12 and 13, Golgi apparatus is well developed and the cytoplasm except for the Golgi zone is filled with abundant secretory granules, blackened after the glutaraldehyde-osmium double fixation. The number of granules are varied from cell to cell, but no extremely degranulated parafollicular cells looking like an empty cell can be observed in the normal thyroid.

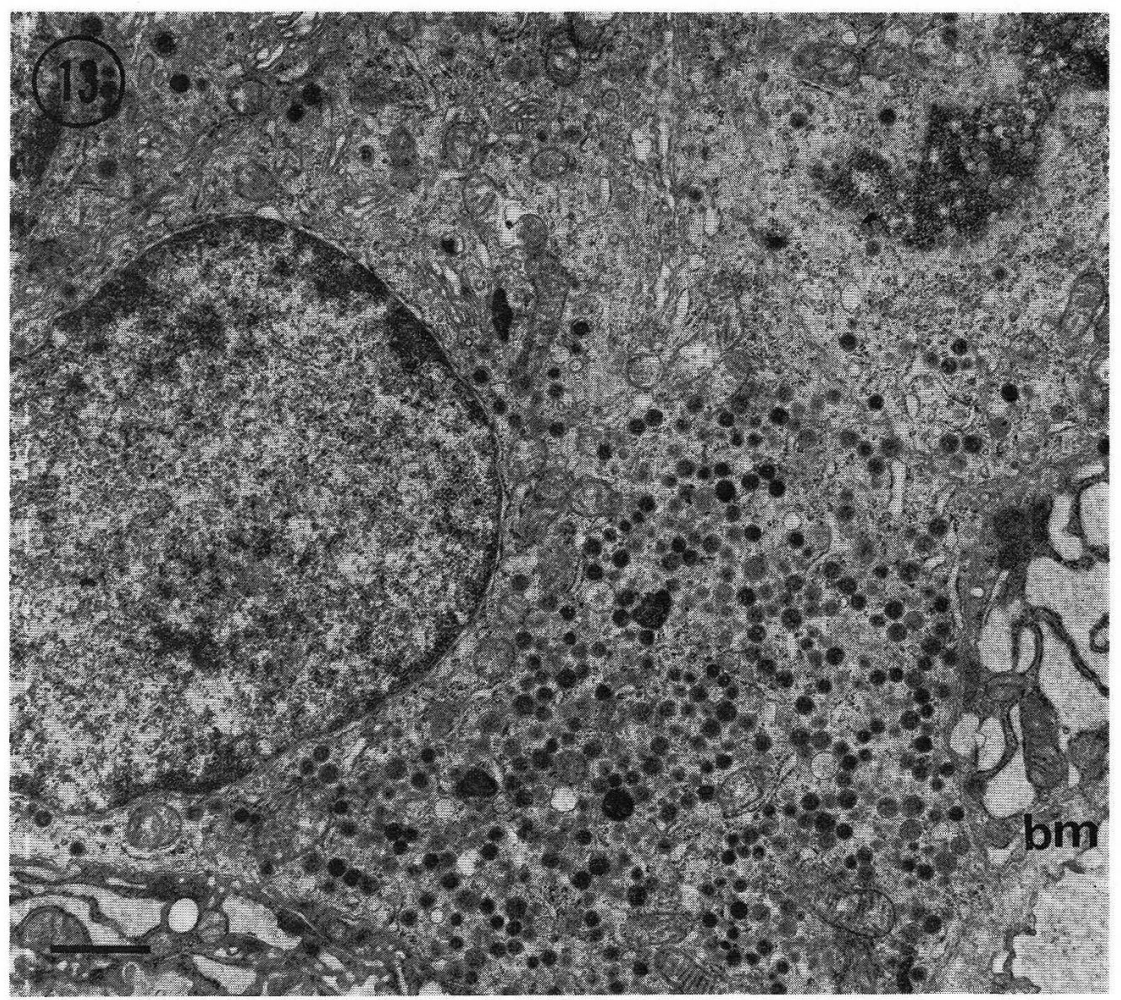

Fig. 13. The parafollicular cell in the normal thyroid fixed with the double fixation of glutaraldehyde-OsO $\mathrm{O}_{4}$. More or less blackened secretory granules are accumulated in the cytoplasm facing the basement membrane $(\mathrm{bm}) . \quad \times 11,000$

The parafollicular cells of the thyroid in the rats injected with calcium solution are shown in Figs. 14 to 18. The secretory granules are also varied considerably from cell to cell as in the case of normal control, but generally there is a tendency for the number of granules to decrease after calcium injection. Two hours after calcium injection, the number of granules already shows a slight decrease, but no prominent morphological changes in the other cell organelles could be found (Fig. 14, 15). On the other hand, four hours after the injection certain numbers of extremely degranulated parafollicular cells, which were never observed in the normal control, appeared intermingled with parafollicular cells containing various numbers of secretory 


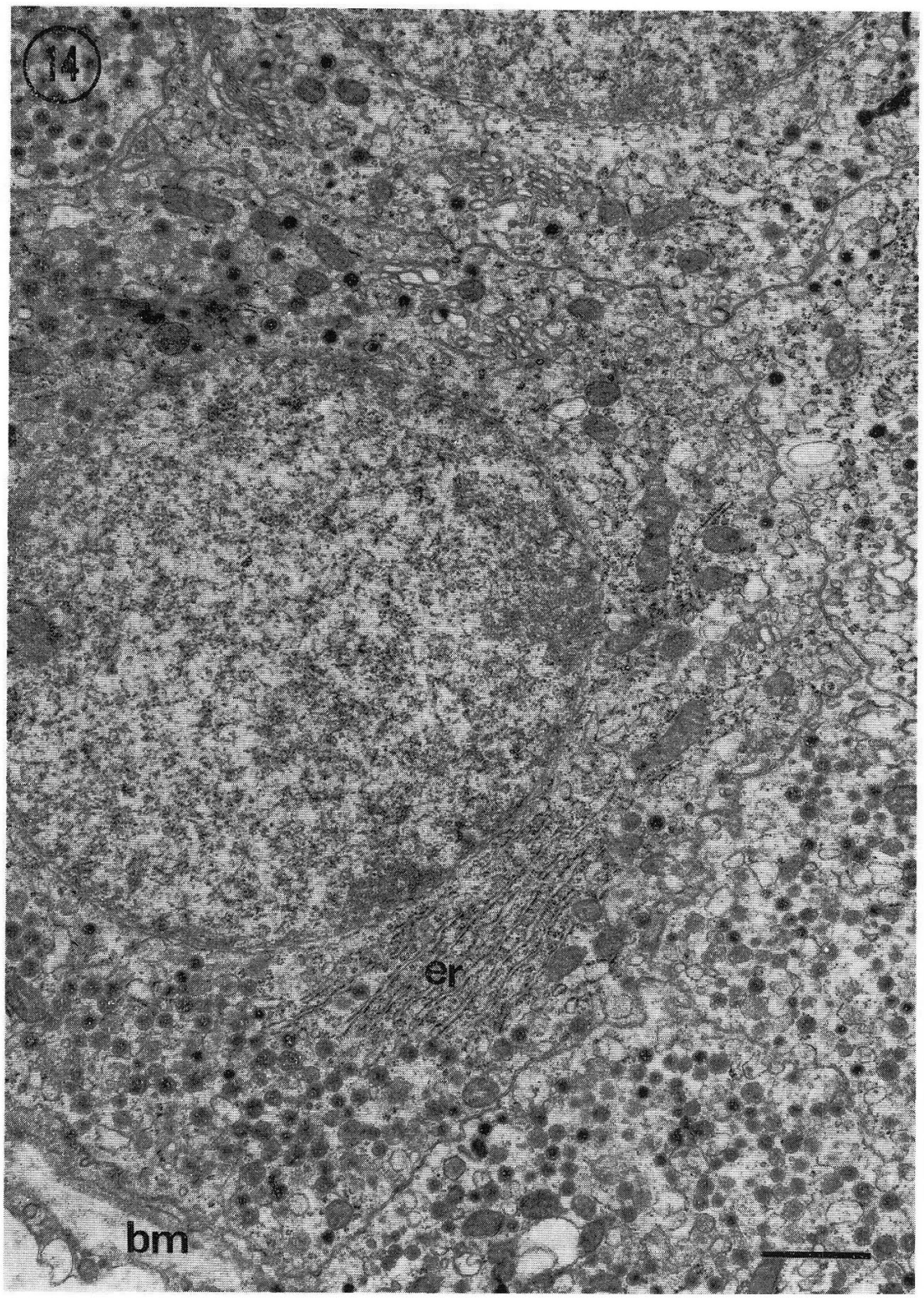

Fig. 14. A part of the group of parafollicular cells 2 hours after calcium injection. The secretory granules are somewhat decreased in distribution density. The rough endoplasmic reticulum (er) consists of lamellae oriented parallel to each other. The basement membrane $(\mathrm{bm})$ and a small part of a blood capillary are observed at the lower left corner. Glutaraldehyde- $\mathrm{OsO}_{4}$ fixation. $\times 13,000$

granules. The Golgi apparatus of the degranulated cell is moderately developed, and the production of secretory granules in the Golgi apparatus is rather active. There are few secretory granules in the cytoplasm, but they do not disappear completely. A few granules tend to 


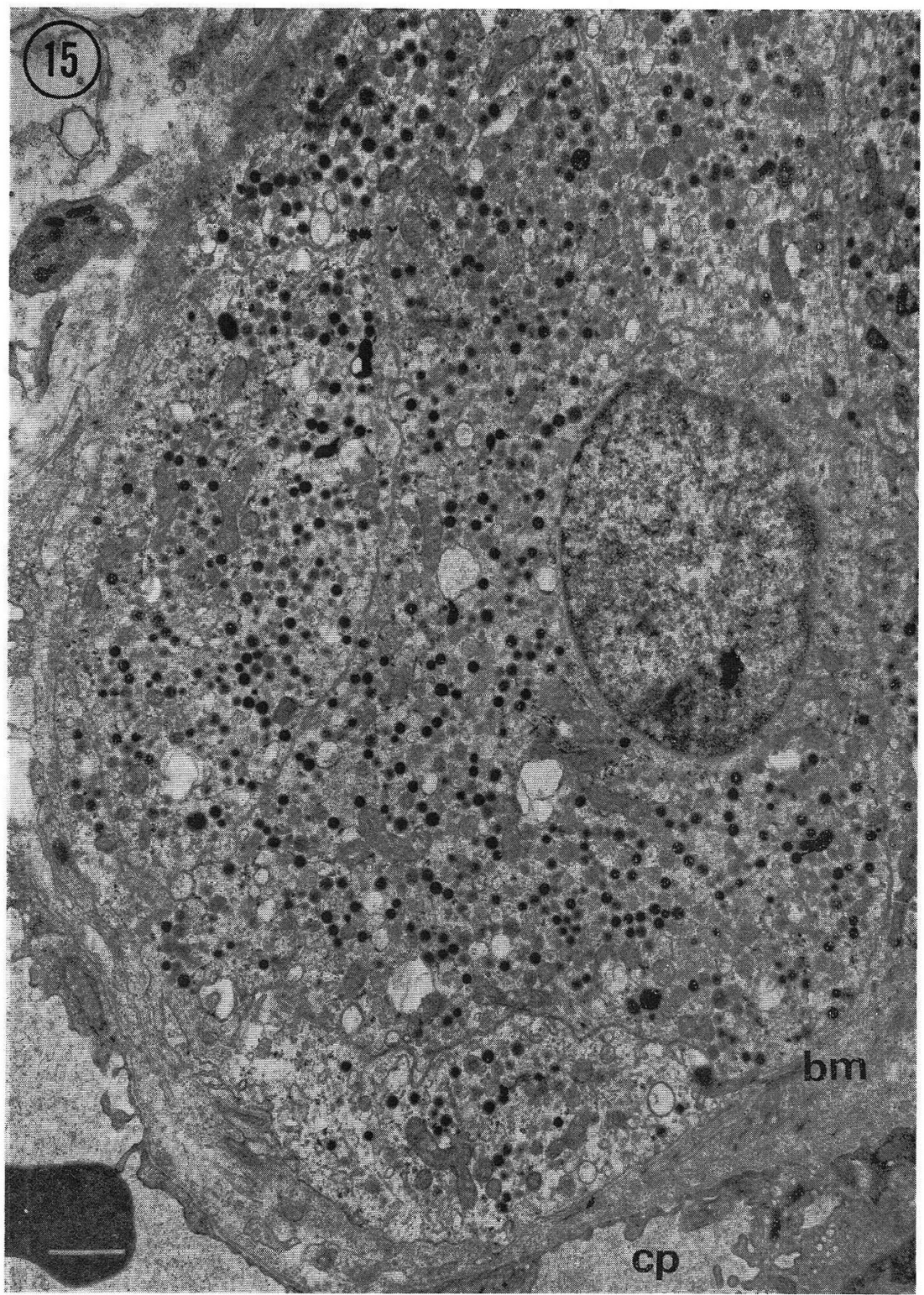

Fig. 15. A group of parafollicular cells of the rat thyroid 2 hours after calcium injection. The cell mass bulges up towards the interstitial lissue, which is separated by a basement membrane $(\mathrm{bm})$ from the parafollicular as well as follicular cells and bears blood capillaries $(c p)$. The parafollicular cells contain a medium number of secretory granules. Glutaraldehyde$\mathrm{OsO}_{4}$ fixation. $\times 9,800$

occur near the Golgi apparatus. Ellements of the rough endoplasmic reticulum were almost totally changed into vesicular forms. Therefore the cytoplasm of the degranulated cells is much clearer than that of the normaly granulated cells. 

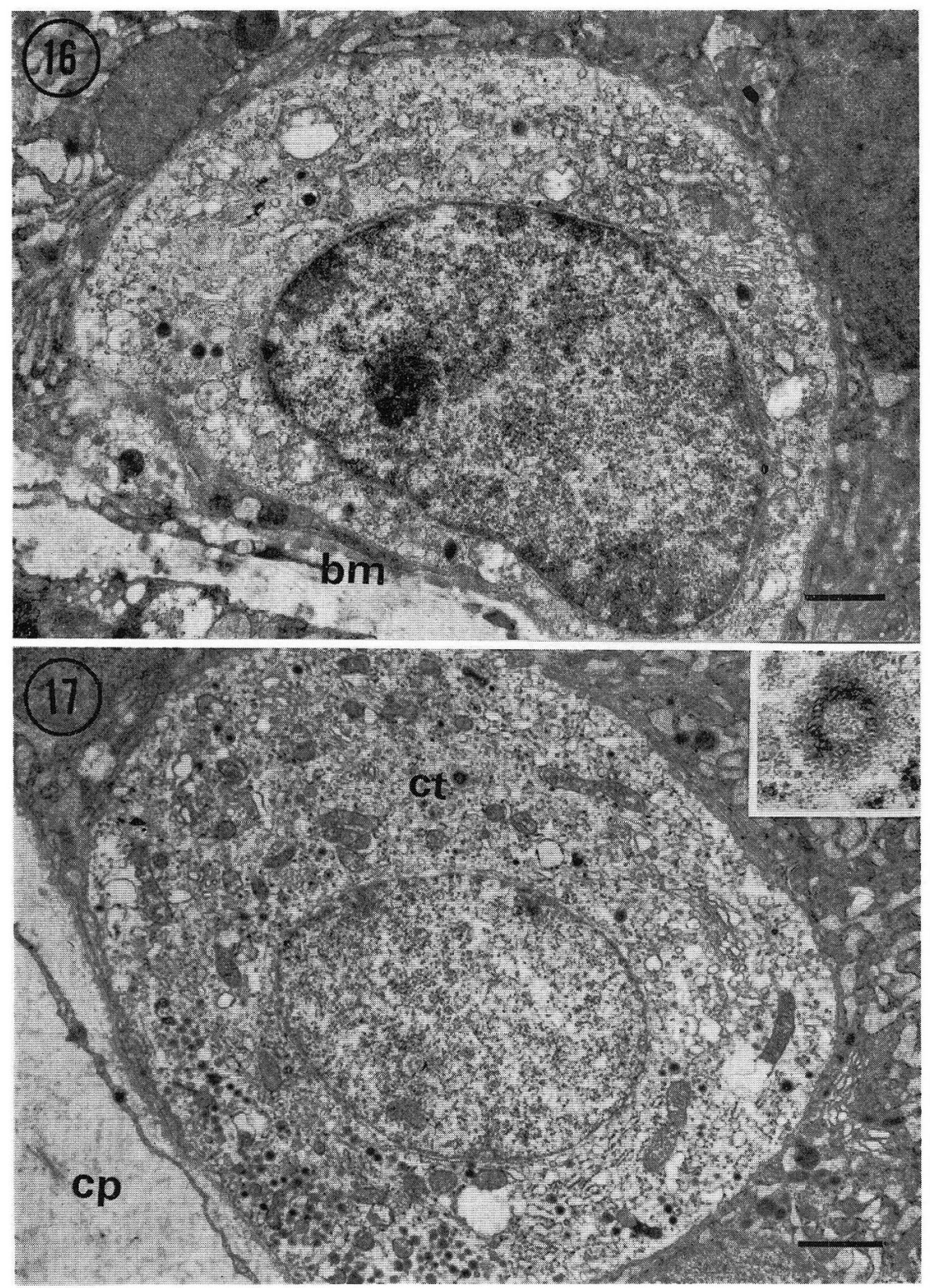

Figs. 16 and 17. The parafollicular cells of the rat 4 hours after calcium injection. In both the pictures degranulation is prominent. The rough endoplasmic reticulum is mostly vesicular in shape and somewhat decreased in volume. Therefore, the cytoplasm appears clear and the cell diminished in volume. $b m$ basement membrane, $c p$ blood capillary, $c t$ centriole. Glutaraldehyde- $\mathrm{O}_{\mathrm{SO}}$ fixation. $\times 10,000$. (The inset is the centriole in a high magnification $\times 64,000)$

As is widely known, hypophysectomy causes the follicular epithelium to atrophy, taking on a strikingly flattened form, with diminution of cell organelles especially of the endoplasmic 


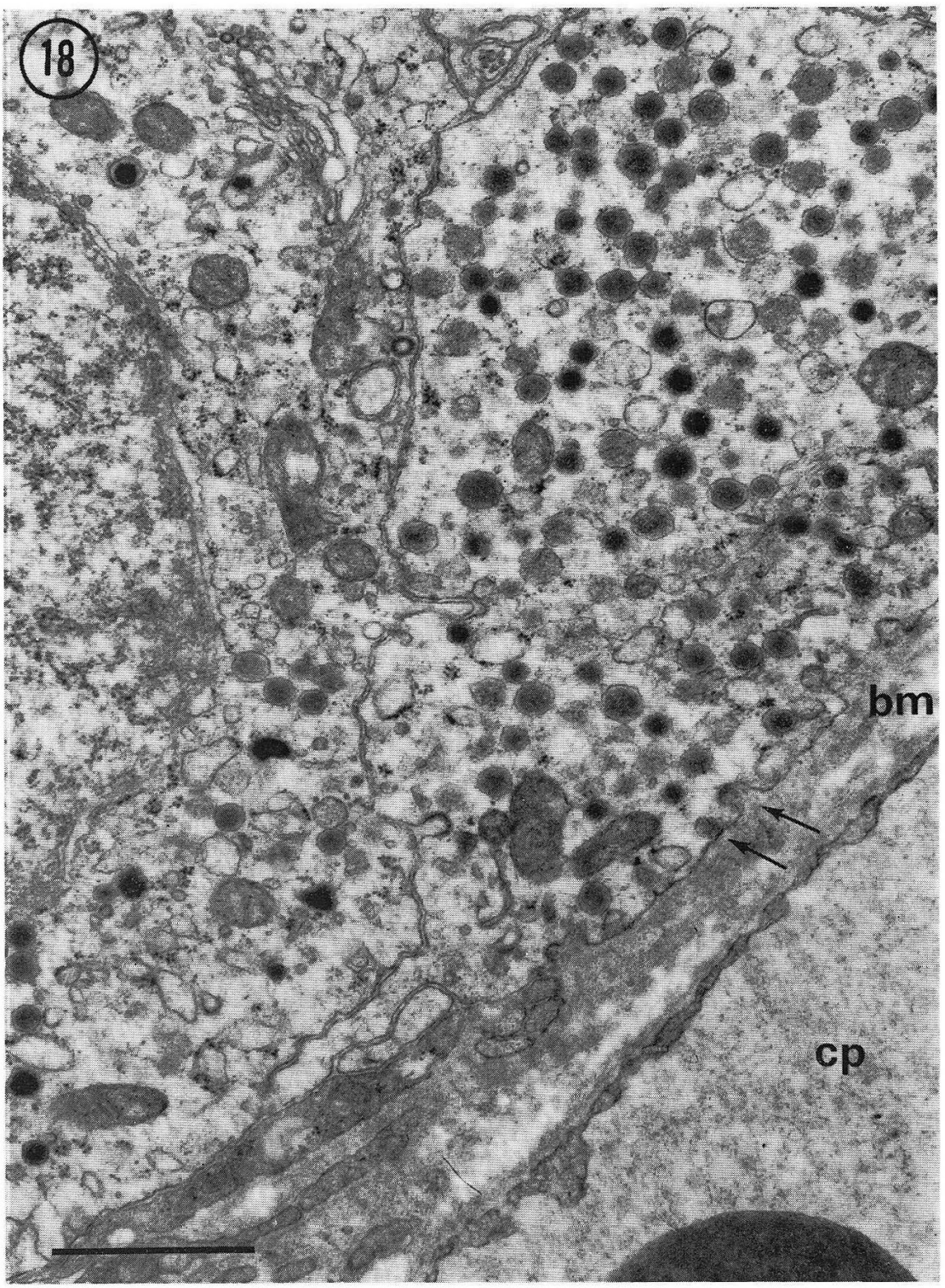

Fig. 18. The basal part of parafollicular cells 4 hours after calcium injection. The dense material contained in the secretory granules, which are situated along the basal plasma membrane, may be discharged through small openings towards the extracellular space facing the basement membrane $(b \mathrm{~m})$ as indicated by arrows. A blood capillary $(c p)$ cantaining a red cell is shown at the lower right corner. Glutaraldehyde- $\mathrm{OsO}_{4}$ fixation. $\times 24,000$

reticulum. On the other hand, the parafollicular cells in hypophysectomized rats do not show any morphological changes (Fig. 19, 20). The secretory granules are still abundant as in the parafollicular cells of the normal control rats, although the number of granules varies from cell to cell. None of the cells corresponding to the so-called degranulated cells appears in the 


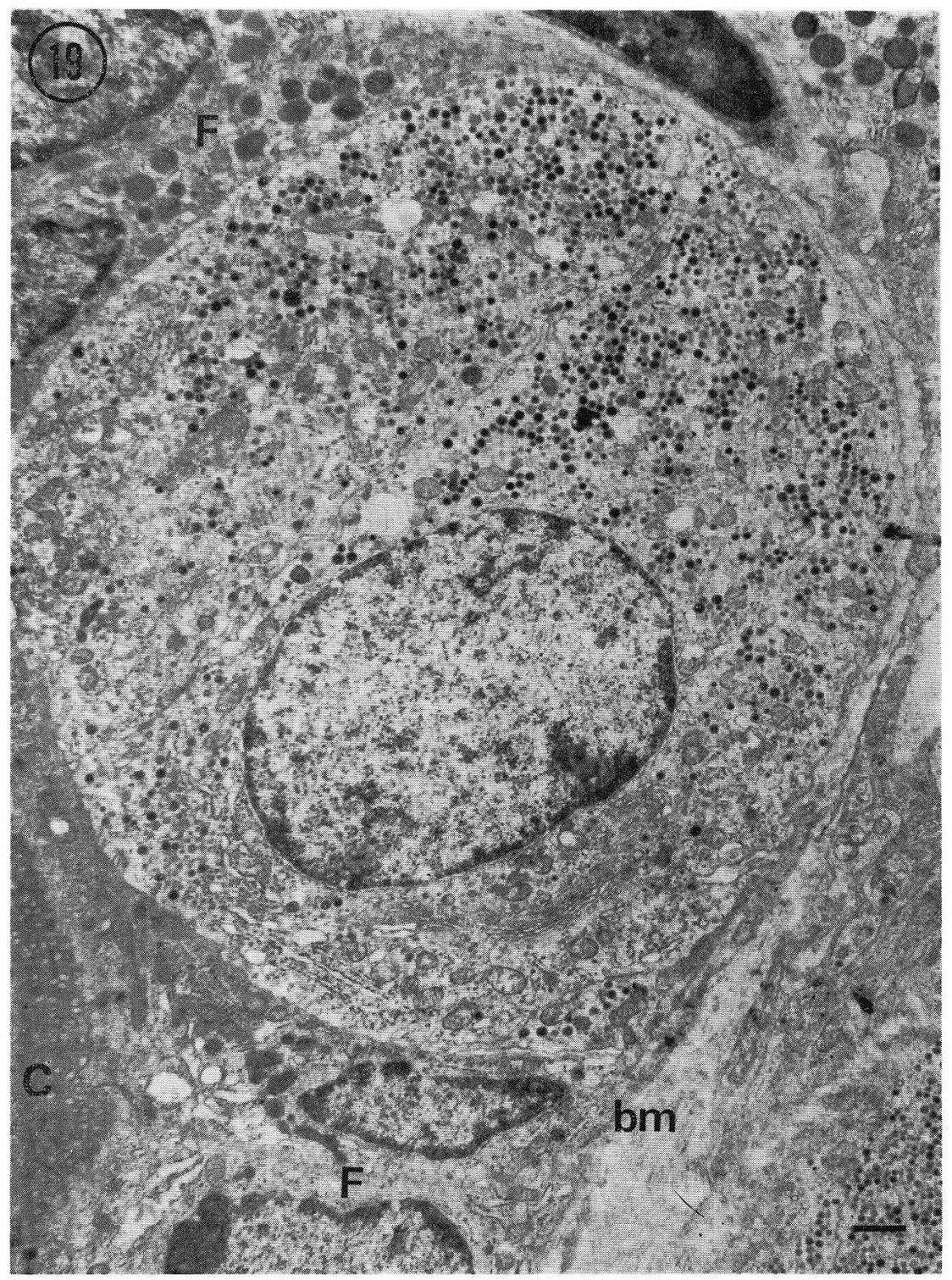

Fig. 19. A part of the thyroid 5 days after hypophysectomy. The secretory granules are abundant just like those of the normal control. On the contrary, follicular cells $\left(F^{\prime}\right)$ show the typical changes resulted from hypophysectomy. $b m$ Basament membrane, $C$ luminal colloid. Glutaraldehyde- $\mathrm{OsO}_{4}$ fixation. $\times 6,400$

thyroids of hypophysectomized rats.

The distribution of population density of secretory granules of the parafollicular cells in each group of the normal and experimental rats is given as the histograms shown in Fig. 21 . The mean density of the normal cells is about $4.5 / \mu^{2}$ and that of the hypophysectomized rats is ąbout 4.3. By the administration of calcium it shịts to 3,4 at 2 hours and 2.1 at 4 hours 


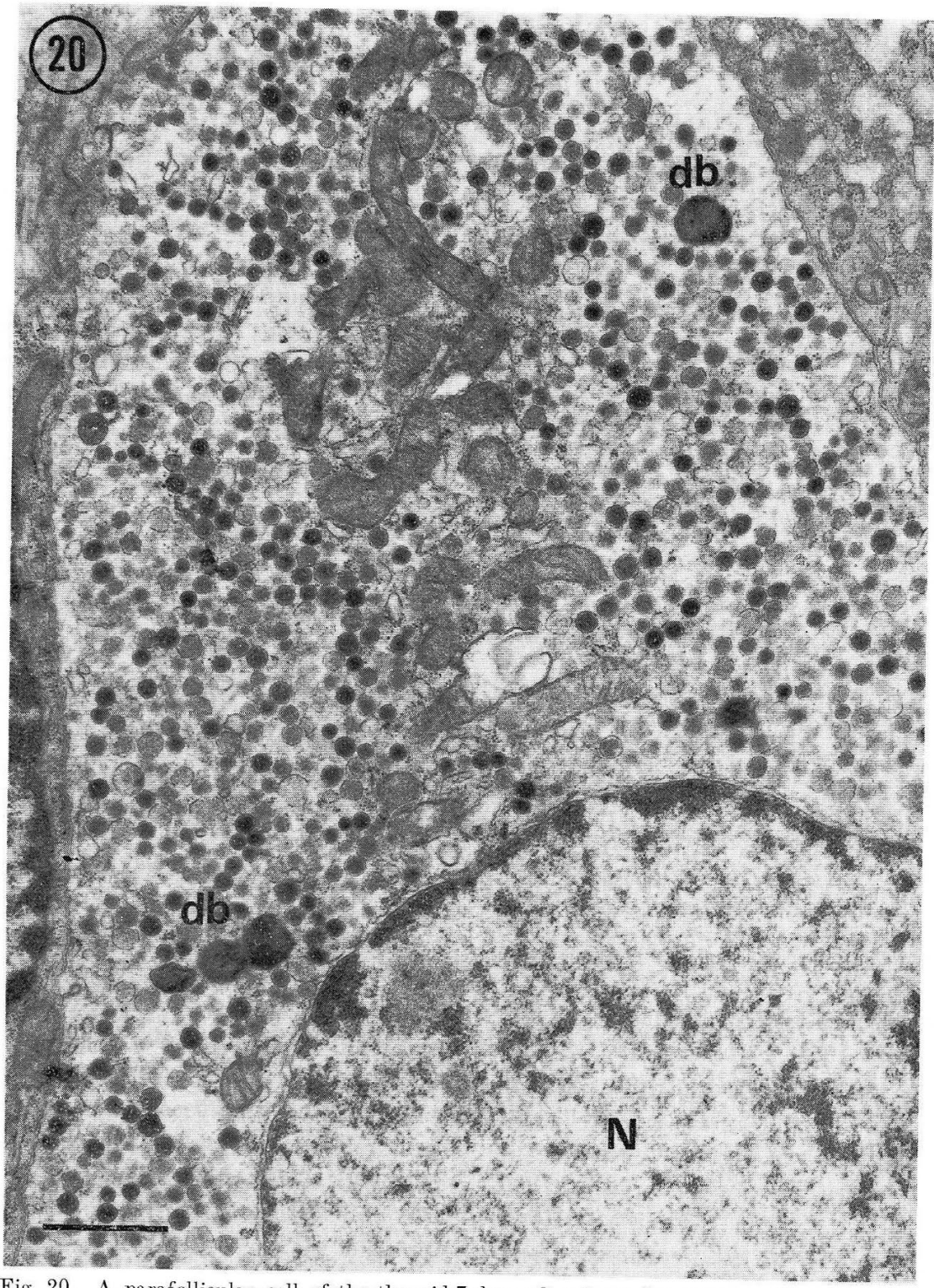

Fig. 20. A parafollicular cell of the thyroid 7 days after hypophysectomy. The cytoplasm is filled with numerous secretory granules. Mitochondria are clustered at about the center of the micrograph. $d b$ Large dense bodies, $N$ nucleus. Glutaraldehyde- $\mathrm{O}_{4} \mathrm{O}_{4}$ fation. $\times 15,000$

after the injection. It must be noted that the population density of secretory granules of the parafollicular cells over $7 / \mu^{2}$ could not be found in the calcium-treated rats. 


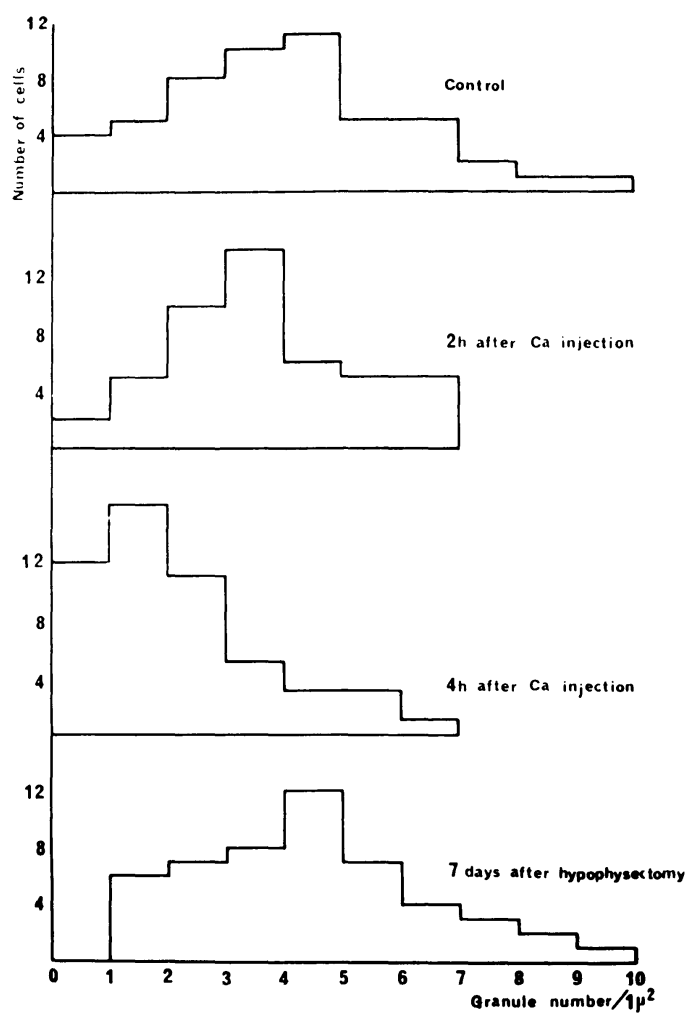

Fig. 21. The histograms indicating the distribution of population density of secretory granules of the parafollicular cells in each experimental group

\section{Discussion}

Another type of glandular cell of the mammalian thyroid besides the ordinary follicular epithelium has been studied by many investigators who called it by various names such as interfollicular epithelium-cell (TAKAGI 1922), parafollicular cell (NoNIDEZ 1932) and light cell (STUx et al. 1961). The term, "parafollicular cell" is adopted in this paper, since this term is most widely used among recent investigators. The fine structure of the parafollicular cells observed with the electron microscope was first described shortly by WISSIG (1962).

Although some early investigators regarded the parafollicular cells as merely tangentially sectioned ordinary follicular cells, the prevailing concept among recent investigators indicates that the parafollicular cell is an independent cell type. As to the problem of origin of this cell, two deverse opinions were proposed: authors of the first group (GODWIN 1937, VAN DYKE 1945, Dumont 1956, Kroon 1958, Tashiro 1964, Aor 1966, SAto et al. 1966) suggested that the parafollicular

cells were from ultimobranchial origin, while another group of investigators (NONIDEZ 1932, SugiYama 1954, Stux et al. 1951, Yoshimura et al. 1962, Ito et al. 1963) reported that the parafollicular cells were derived from the ordinary follicular cells. YosHimuRA et al. (1962) suggested that the parafollicular cells and follicular cells were capable of transition and that the reversible transformation between them was controlled by thyrotrophic hormone.

It is well known that the parafollicular cells exist in almost all mammalian species. STUX et al. (1961) confirmed that the parafollicular cells were distributed chiefly in the follicles of the central region, but were absent from the isthmus of the rat thyroid. They also reported that the number of the parafollicular cells in rats was very small (one or a few percent of the total population of epithelial cells). Recently ITO et al. (1963) reported the existence of a large number of parafollicular cells in the raccoon dog. In the present study, the author felt that the parafollicular cells were rather easily recognized in each thyroid of experimental animals as well as the normal control, though the specimens were not obtained from any particular limited regions of the thyroid lobe. The double fixation with glutaraldehyde and osmium tetroxide seems to make the parafollicular cells easier to detect.

The functional significance of the parafollicular cells also has been discussed by many authors, Some of them supposed that the parafollicular cells might be concerned in formation 
of new follicles (Ehrenbrand 1954, Sugiyama 1954, Saito and Shibata 1957, Kraicziczek 1956, Yoshimura et at. 1962 Ito et al. 1963). On the contrary, other investigators considered the parafollicular cells to be secreting cells (TAKAGI 1922, Nonidez 1932, Florentin 1932, Allara 1939, Sugiyama 1950 and 1954, Saito 1956, Yoshimura et al. 1962). TaKagi (1922) suggested the possibility that the secretory product of parafollicular cells is extruded directly towards the interstitium. YouNG and LEBLOND (1963) assumed that the parafollicular cells might be formed from the follicular cells, as the result of degeneration of the latter due to the fact that the cell lost a contact with the colloid and became unable to discharge their secretory product. In 1964, LUCIANO and REALE observed the fact that the secretory vesicles were opened to the extracellular space facing the basement membrane and the secretory product might be discharged through its opening. But they reported that such findings suggesting secretion mechanism of the parafollicular cell were rarely found. In the present study with the use of glutaraldehyde fixation, the secreion discharge was through a small hole, and was observed more frequently and more clearly than reported by LUCIANO and REALE (1964).

Concerning the probable hormone dependency of the parafollicular cell, SAITO and SHIBATA (1957) reported in the rat that neither were morphological changes found with the administration of thyrotrophic hormone, nor was the number of cells increased by hypophysectomy. THOMPSON et al. (1962) also studied the effect of hypophysectomy and administration of growth hormone. They observed the fact that the parafollicular cells increased in number after hypophysectomy, and that the growth hormone induced an increase in number of parafollicular cells in the rat. Furthermore, they indicated that a combination of the two procedures might multiply the effect on the thyroid parafollicular cells, that is the number of parafollicular cells in the rats hypophysectomized and treated with growth hormone increased more than those after either hypophysectomy or administration of growth hormone alone. The hyperplasia and proliferation of parafollicular cells by hypophysectomy and administration of thyroxine were observed by Yoshimura et al. (1962). They found, on the other hand, that the parafollicular cells either diminished in number or disappeared, when thyrotrophic hormone was administered. In the present investigation, however, no morphological changes in the parafollicular cells could be observed in the hypophysectomized rat.

On the other hand, the histochemical properties of parafollicular cells were studied by SANDRITTER et al. (1956). They described how the parafollicular cells contained lipid, glycoprotein and others, and that the activity of alkaline phosphatase and nospecific esterase in parafollicular cells was moderate and the degree of reaction between parafollicular cells did not differ. GABE et al. (1959) obtained almost the same results as SANDRITTER et al. (1956) concerning enzymatic activity of parafollicular cells. According to FOSTER et al. (1964), in the thyroid gland perfused with the blood of high calcium level, acid phosphatase activity was definitely increased and the level of $\boldsymbol{\alpha}$-glycerophosphatase dehydrogenase and nonspecitic esterase activity were distinctly lower in parafollicular cells. Their results indicated definitely that the parafollicular cells were concerned in some way with the metabolism of calcium.

The parafollicular cells are quite different in morphological structure from ordinary follicular cells. Furthermore many investigators suggested the possibilities of active production of some secretory material which might be independent of thyrotrophic hormone control by the anterior hypophysis. There is no substantial evidence to solve the question of whether or not the secretory materials of parafollicular cells may be the same substance as the serum calcium-lowering factor or calcitonin, whịch wạs dịscovered by CopP et al. (1962) and was 
confirmed to be a new hormone contained in the thyroid gland by Hirsch et al. (1963, 1964) and Foster et al. (1964).

In the present study, degranulaion of parafollicular cells is definitely recognized after administration of calcium solution. Almost empty cells appeared within four hours after calcium injection. These cells cannot be found in the normal thyroid, but are seen only in this experimental condition. Luciano and Reale (19j4) also described the "protoplasmaarme Zelle", which has clear cytoplasmic projections. The amount of cytoplasm in this cell is small and its cell-organelles are poorly developed. Therefore the "protoplasmaarme Zelle" are quite different from the degranulated cells observed in the present study. Furthermore, Foster et al. (1964) demonstrated an extensive vacuolation in cells of the thyroid gland perfused with the blood of low calcium level. They considered that this vacuolation might well be regarded as an artefact, but there was no reason to ignore its significance on that account. In the present study extremely degranulated cells appeared at four hours after calcium injection, and at that time the serum calcium level was at its minimum. The vacuolation demonstrated by Foster et al. (1964) are extensive in the parafollicular cells and yet the vacuolated cells appear to be in a group on their photomicrograph. On the other hand, the degranulated parafollicular cells observed in the present study shows a tendency to appear singly, being intermingled with the granulated parafollicula cells retaining various degrees of granulation. In spite of the wide variation in granule popuation from cell to cell, the number of granules is usually reduced in the calcium administered group, as shown in the histograms in Fig. 21. The degranulation of parafollicular cells may be regarded as a functional condition exhausting their secretory granules. Therefore the acute administration of calcium solution may eliminate the secretory granules almost completely. From these findings, it is most likely that the parafollicular cells might secrete the serum-calcium lowering factor or thyrocalcitonin, release of which is most evident after the administration of calcium. The parathyroid gland has not been observed simultaneously in the present study of calcium influence. Further studies on the relationship between the parafollicular cells and the production of thyrocalcitonin must be performed on the basis of the new data including the changes, if any, of the parathyroid cells.

\section{Summary}

The parafollicular cells of the thyroid glands in the normal, calcium-injested and hypophysectomized rats were observed with the electron microscope, with special reference to their secretory granules. The general structures in normal and experimental conditions of the parafollicular cells were described in detail. Two hours after calcium injection, the number of secretory granules showed a slight decrease, but no prominent morphological changes related to the other cell organelles could be found. Four hours after the injection a certain number of extremely degranulated parafollicular cells appeared, being intermingled with parafollicular cells which contain various numbers of secretory granules. In hypophysectomized rats, no morphological changes could be found and the secretory granules were still as abundant as in the normal control. The distribution of population density of secretory granules of the parafollicular cells in each group of the normal, the calcium-injected and the hypophysectomized rats was measured. Following the administration of calcium, the number of granules clearly decreased. The functional significance of the parafollicular cells was not totally clarified, but it is most likely that the parafollicular cells secrete thyrocalcitonin. 
Acknowledgement. Much of this work was suggested by Prof. Kazumasa Kurosumi, to whom I owe thanks for his interest and help in the course of this work. I am also indebted to members of the staff of the Department of Morphology for their assistance in carrying out the experiments. Thanks are also due to Prof. Keizo Ishinara for giving me the opportunity for the investigation.

\section{ラット甲状腺旁小胞細胞の実赜形態学的研究, とくにサイロカルシトニンの 起源に関して (内容自抄)}

正常対照，カルシウム注射，および下垂体摘除の 3 群に分けたラットの各群について， 甲状腺の旁小胞細胞を電子顕微鏡により観察し， とくに分泌顆粒の数的変化に着目して， その分布密度を計測した。グルタールアルデヒド前闹定後オスミウムで周定した材料は， 旁小胞細胞の分泌顆粒がすべて暗調にみえるので，乙の種の研究には有用である，先ず対 照群之実験群の旁小胞細胞の一般的微細構造を咩細に観察し記載した。 カルシウム注射群 では注射後 2 時間で分泌顆粒数が僅かに減少するが, 細胞内小器官は著明な形態学的変化 を示さない，カルシウム注射後 4 時間において極度に脱顆粒をを起こした旁小胞細胞が出現 した。下垂体摘除群では旁小胞細胞は何ら形態学的変化を示さず，その顆粒数も対照群と ほぼ同程度である。分泌顆䊑の分有密度は正常において $4.5 / \mu^{2}$, 下垂体摘除群で $4.3 / \mu^{2}$ であるが, カルシウム注射後 2 時問で $3.4 / \mu^{2}$ に，4 時間後には $2.1 / \mu^{2}$ に減少する.

堂小胞細胞の機能はまだ完全には明らかにされていないが，上䚶の結果から，血清カル シウム低下因子として㓫られるサイロカルシトニンの産生細胞であろうという可能性が非 常に大きい.

\section{References}

Allara, E : Contributo alla conoscenza dell' origine e del significato dell' epitelio interfollicolare della gh:andola tiroide. Z. Zellforsch. $29: 138-200$ (1939).

Aoi, $\mathbf{T}$. : Electron microscopic studies of the follicle cells and parafollicular cells in the thyroid gland of the primates. Fol. anat. jap. 42 : 63-89 (1966).

Caulfield, J. B.: Effects of varying the vehicle of $\mathrm{OsO}_{4}$ in tissue fixation. J. biophys. biochem. Cytol. $3: 827-830$ (1957).

Copp, D. H , E. C. Cameron, B. A. Cheney, A. G. F. Davidson and K. G. Henze : Evidence for calcitonin-A new hormone from the parathyroid that lowers blood calcium. Endocrinology, $70: 638$ 649 (1962).

Dumont, L. : Activité cholinestérase de cellules parafolliculaires de la thyroide. C. r. Ass. Anat. Paris 3 : 480-485 (1956).

Ehrenbrand, F : Untersuchungen über Genese und Funktion der parafollikulären Zellen der Schilddrüse. Z. mikrosk. anat. Forsch: $60: 337-354$ (1954).

Florentin, P.: La glande thyroide des mammifères. Thèse Méd. Nancy, Georges Thomas, 1932.

Foster, G. V., I MacIntyre and A. G E Pearse: Calcitonin production and the mitochondrion-rich cells of the dog thyroid. Nature, $203: 1029-1030$ (1964).

Gabe, M.: Données histochimiques sur les cellules parafolliculaires de la glande thyroide du chien. Acta anat. $38: 332-344$ (1959).

Godwin, M. C.: Complex IV in the dog with special emphasis on the relation of the ultimobranchial body to interfollicular cells in the postnatal thyroid gland. Amer. J. Anat. 60 : 299-339 (1937).

Hirsch, P. F, G. F, Gauthier and P. L Munson: Thyroid hypocalcemic principle and reccurent laryngeal nerve injury as factors affecting the response to parathyroidectomy in rats. Endocrlinology, 73 : 244-252 (1963). 
Hirsch, P. F., E. F. Voelkel and P. L. Munson: Thyrocalcitonin : Hypocalcemic hypophosphatemic principle of the thyroid gland. Science, $146: 412-413$ (1964).

Ito, T., Y. Takahashi und K. Koboyashi : Über die Parafollikularzellen der Schilddrüse von einem Nyctereutes procyonoides viverrinus. Arch. histol. jap. 24 : 113-127 (1963).

Koyama, R.: A simple method of hypophysectomy in rats (Koyama's external auditory canal method). Endocrinol. jap. 9 : 312-323 (1962).

Kraicziczek, M.: Histogenese und Funktionszustand der embryonalen Hühnerthyreoidea. Z. Zellforsch. $43: 421-458$ (1958).

Kroon, D. B.: The macrothyrocytes as a functional stage of the thyroid cell. Acta anat. 33: 76-104 (1958).

Kurosumi, K.: Electron microscopic analysis of the secretion mechanism. Int. Rev. Cytol. 11:1-124 (1961).

Luciano, L. und E. Reale : Elektronenmikroskopische Beobachtungen an parafollikulären Zellen der Rattenschilddrüse. Z. Zellforsch. 64 : 751-766 (1964).

Luft, J. H.: Improvements in epoxy resin embedding method. J. biophys. biochem. Cytol. 9:409-414 (1961).

Millonig, G. : A modefied procedure for lead staining of thin section. J. biophys. biochem. Cytol. 11: 736-739 (1961).

Nonidez, J. F.: The origin of the parafollicular cell, a second epithelial component of the thyroid of the dog. Amer. J. Anat. 49 : 479-495 (1932).

- Further observations of the parafollicular cells of the mammalian thyroid. Anat. Rec. $53: 339$ 347 (1932).

Sabatini, D. D., K. Bensch and R. J. Barrnett: The preservation of cellular ultrastructure and enzymatic activity by aldehyde fixation. J. Cell Biol. $17: 19-58$ (1963).

Saito, K.: Experimental studies on the thyroid gland with special reference to the parafollicular cells (Japanese). Kitakanto med. J. 6 : 511-525 (1956).

Saito, K. and K. Shibata : Parafollicular cell in the rat thyroid. Endocrinol. jap. $4: 253-261$ (1957).

Sandritter, W., E. Kummer, G. Fillat and L. Röwe : Zur Histochemie und Funktion der Parafolliculären Zellen in der Schilddrüse. Klin. Wochenschr. 34 : 871-872 (1956).

Sato, T., K. Ishikawa, T. Aoi, J. Kitoh and S. Sugiyama : Electron microscopic observations on the development of the parafollicular cells from the ultimobranchial cyst in the thyroid gland of the mouse. Fol. anat. jap. 42 : 91-105 (1966).

Stux, M., B. Thompson, H. Isler and C. P. Leblond : The "light cells" of the thyroid gland in the rat. Endocrinology, $68: 292-308$ (1961).

Sugiyama, S: Studies of the histogenesis of the thyroid gland of the guinea pig. 1. The thyroid cells (follicle cells and parafollicular cells). Anat. Rec. 120 : 363-378 (1954).

- : On the postnatal histogenesis of the thyroid gland of the rabbit. 1. On the glandular cell (follicle cell and parafollicular cell). Fol. anat. jap. $23: 57-64$ (1950).

Takagi, K. : A cytological study on the dog's thyroid gland. Fol. anat. jap. $1: 69-100(1922 / 23)$,

Tashiro, M. : Electron microscopic studies of the parafollicular cells in the thyroid gland of the dog. Fol, anat. jap. 39 : 191-211 (1964).

Thompson, B., H. Isler and K. Sarker : Effect of hypophysectomy and grow th hormone on the light cells of the thyroid gland. Endocrinology, $70: 786-795$ (1962),

Van Dvke, J. H.: Behavior of ultimobranchial tissue in the postnatal thyroid gland: Epithelial cysts, their relation to thyroid parenchyma and to "newgrowths" in the thyroid gland of young sheep. Amer. J, Anat. $76: 201-251$ (1945).

Wissig, S. L. : The fine structure of parafollicular (light) cells of the rat thyroid gland. Electron Microscopy. 2 : WW-1 (1962),

Yoshimura, F., T. Yonetsu and M. Nakamura : Hormonal regulation of parafollicular cell in the thyroid gland. Endocrinol. jap. 9 : 284-301 (1962).

Young, B. A. and C. R. Leblond : The light cell as compared to the follicular cell in the thyroid gland of the rat. Endocrinology, $73 ; 669-6866$ (1963). 